\title{
Irish nationalism and the uncanny: a reading of "The ghost of Roger Casement"
}

\author{
Nacionalismo irlandês e fantasmagoria: uma leitura de "The ghost of Roger Casement" \\ Mariana Bolfarine \\ Universidade de São Paulo - São Paulo - São Paulo - Brasil \\ $\diamond$
}

\begin{abstract}
Of the several fictional works about the Irish revolutionary Roger David Casement, none has reached the notoriety of William Butler Yeats's poem "The ghost of Roger Casement" (1936). Roger Casement is known for acting as British Consul in Africa and in Brazil, having reported atrocities committed against the natives in these regions by imperial rubber companies. The aftermath of having witnessed the effects of such atrocities eventually turned Casement against the British Empire for which he was sentenced to death for high treason. However, the heart of the controversy that surrounds his afterlife lies in the fact that he was prevented from achieving martyrdom because a set of homosexual diaries was found by the British Foreign Office and prevented a reprieve. This paper investigates, in the first place, the background in which the poem was written and to trace the mutual influence and admiration Roger Casement and WB Yeats felt for each other. In the second, it demonstrates that Casement's uncanny representation in "The ghost of Roger Casement" is the result of the merging of Yeats's knowledge of Celtic mythology and folklore combined with his nationalist views towards Ireland and negative impressions of British imperialism.
\end{abstract}

Keywords: Roger Casement; WB Yeats; Nationalism; Uncanny

Resumo: Das diversas obras ficcionais sobre o revolucionário irlandês Roger Casement David, alcançou a notoriedade do poema "The ghost of Roger Casement" (1936) do irlandês William Butler Yeats. Roger Casement é conhecido por ter sido cônsul britânico na África e no Brasil, tendo relatado atrocidades cometidas contra os nativos dessas regiões por empresas coletoras de borracha. O resultado de ter testemunhado os efeitos de tais atrocidades foi que Casement se voltou contra o Império Britânico e, logo, condenado à morte por alta traição. No entanto, o cerne da controvérsia que envolve seu legado deve-se aos diários de cunho homossexual encontrados pelo Ministério de Relações Exteriores britânico que impediram a possibilidade de um indulto. Este trabalho investiga, em primeiro lugar, o contexto em que o poema foi escrito e verificar a influência e a admiração que Roger Casement e WB Yeats sentiam um pelo outro. Em segundo lugar, demonstra que a representação fantasmagórica de Casement em "The ghost of Roger Casement" é o resultado da fusão do conhecimento de Yeats da mitologia e folclore celtas combinado com seu posicionamento nacionalista em relação à Irlanda e impressões negativas frente ao imperialismo britânico.

Palavras-chave: Roger Casement; WB Yeats; Nacionalismo; Fantasmagoria

\section{Introduction}

Of the numerous fictional works written about the Irish revolutionary Roger David Casement, none has reached the notoriety of William Butler Yeats's poems, chiefly, "The ghost of Roger Casement" (1936). Apart from being British Consul in Africa and in Brazil, Roger Casement has undergone many other herculean tasks, namely, reporting atrocities committed against the natives in the Congo and in the Amazon due to their exploitation as rubber gatherers for imperial companies, respectively King Leopold's Congo Free State, and the Peruvian Amazon Company registered in London, which rendered him knighthood, among other titles.

The aftermath of having witnessed the effects of such atrocities eventually turned Casement against the 
British Empire, and he ultimately sought German support at the outbreak of the First World War to fight for the independence of Ireland that would culminate in the Easter Rising, in April, 1916. For that, he was sentenced to death for high treason and was hanged on $3^{\text {rd }}$ August of that same year. However, the heart of the controversy that has surrounded his image in his afterlife is the fact that, different from the other 15 rebels executed in the Rebellion, he was prevented from achieving martyrdom because a set of homosexual diaries, the so-called Black Diaries, was found by the British Foreign Office and copies of some of its excerpts were distributed among his supporters.

This paper aims to investigate, in the first place, the background in which the poem was written and to trace the mutual influence and admiration Casement and Yeats felt for each other. In the second, it intends to demonstrate that Casement's uncanny representation in "The ghost of Roger Casement" is the result of the merging of Yeats's knowledge of Celtic mythology and folklore combined with his nationalist views towards Ireland and negative impressions of British imperialism.

\section{The crossing paths of WB Yeats and Roger Casement}

Yeats and Casement were born in county Dublin - the former in Sandymount, in 1865, the latter in Sandycove, in 1864 - and spent their childhood in the north of Ireland, respectively in Sligo and Ballycastle. This mixed background that both men had in common was to have a great impact on Yeats's late work as well as on Casement's final years and afterlife. According to biographer Roy Foster, Yeats, in the manner of Jonathan Swift, was an Anglo-Irish Protestant as well as a proud Irish nationalist:

From the national viewpoint WB Yeats occupies an almost unique position in Irish life; for he is virtually the first man since Swift who has been able to bring the Anglo-Irish tradition into line with a positive nationalism. He took inspiration from the ancient Celtic legends in the west; but has always been proud of the fact that he comes of Anglo-Irish stock [...] (FOSTER, 2003, p. 520)

Having been raised in a house surrounded by writers and artists, with the help of his patron, Lady Augusta Gregory, Yeats became the leading figure of the Irish literary and culture revival whose aim was to recover Ireland's long lost tradition, and together they founded the Irish Literary Theatre, which, in 1904, became known as the Abbey Theatre. Although he would write poetry and drama charged with nationalism, he avoided to mingle art and contemporary politics, chiefly in his early career. He condemned especially the use of art as political propaganda, for he thought that the idealized Irish past of Celtic mythology and folklore was the proper stuff of which his writings should be made, and especially after the 1922-1923 Civil War, he remained nostalgic of the time the Anglo-Irish Ascendency were the ruling class in Ireland.

Likewise, Casement was of Ulster stock and had been a Protestant throughout his life having, however, been secretly baptized Catholic by his mother when he was three years of age and had himself converted to Catholicism during his arrest, shortly before reaching the gallows. He adored the north of Ireland, where many of the Casements still live in Margherintemple, his family home, and his last wish was to be buried in the Glens of Antrim. Still, as it will be discussed later in this paper, due to the charge of treason, his body was unwelcome in the north and his burial in Glasnevin Cemetery, in Dublin is, even today, object of much controversy.

According to his cousin Gertrude Bannister, since an early age Roger Casement nurtured sympathies for nationalist heroes:

In his school days he begged from the aunt, with whom he spent his holidays, for possession of an attic room which he turned into a little study, and the writer remembers the walls papered with cartoons cut out of the Weekly Freemen, showing the various Irish Nationalists who have suffered imprisonment at English hands for the sake of belief in Ireland a nation. (O’SÍOCHÁIN, 2008, p. 14)

After the death of his parents and having been raised by Protestant relatives in Ulster, Casement, as a young man of 16, left Ireland for Liverpool, where he worked for the Elder Dempster Shipping Line, and from there made his way to Africa. In the beginning of his consular career Casement was a diligent employee of the Crown, and it was only after the time he spent in the Belgian Congo that he began, along his friend and journalist ED Morel, founder of the Congo Reform Association, to secretly plot against the British Empire. According to Foster, different from Casement, during most of his life Yeats wished to keep distant from politics as his main interests lay in mysticism and the occult. In spite of this, after 1914 he had decided to write poems that would " not be a dream, like my earlier poems, but a criticism of life.' He would plumb his family and personal history, his own wrangle with Irish politics, and his supernatural searches as the material for his art" (FOSTER, 2003, p. 1).

Biographer Brian Inglis (1973) believes Yeats's well known poem "September 1913" - which refers to the Dublin Lockout that urged workers to take part in 
unions, at the same time claiming that "romantic Ireland is dead and gone" - reflected Casement's feelings as well. Casement was also a great admirer of Yeats's poems: his favourite, as he had told Alice Green two years earlier, was "The Lover tells of the Rose in his Heart", which foregrounds a romantic side to his character and personality that goes hand in hand with his devotion to and de facto involvement first with the natives in both the Congo and in the Putumayo ${ }^{1}$, and with the Irish nationalist cause later in life. Casement had also read Yeats's works concerned with the Irish Revival, and he was really enthusiastic about Cathleen ni Houlihan (1902), a play in which the shan van vocht (the poor old woman) is a representation of Ireland that urges its young men to fight for Irish freedom. According to Brian Inglis (1973), Casement spoke much of it to his friends, the historian Alice Stopford Green and Henry W. Nevinson, one of the most respected journalists of the time, who had met him and found him " "pervaded and obsessed' by Ireland" (INGLIS, 1973, p. 133).

Nevertheless, as the course of events began to change Yeats's concern with politics became graver after the 1916 Easter Rising, a rebellion that sought independence from Britain, which, at first, he did not take seriously. His lack of belief in the Rising is made clear on an occasion when Yeats visited his friend Charles Ricketts four days after it had taken place. Ricketts noted and commented upon his "strange Irish impartiality" (p. 46), while WB Yeats's response to him was that "a paternal government would discover Roger Casement was insane, imprison the leaders during the war pending investigations over the extent of German intrigues in the matter, discover that these men were disguised dupes, and probably amnesty them after the war" (FOSTER, 2003, p. 47).

All the same, history shows that the outcome of the Rising was quite different from what Yeats had first thought after the execution of the 15 Irish rebels in Kilmainham Gaol, Dublin, being Casement the $16^{\text {th }}$ and last to die in the gallows of Pentonville Prison, London, on 3 August, 1916. Although he had never been involved in politics, a reprieve was being organized by Casement's friends and supporters; thus, "WB Yeats wrote personally to Asquith, from Calvados, claiming that though he had never approached a minister of the Crown before, he must express his opinion that the execution of Roger Casement would be evil" (INGLIS, 1973, p. 353).

Despite Yeats's insistence that he would not meddle with political affairs, at the urging of Maud Gonne, his lifelong beloved who was also a keen supporter of

\footnotetext{
The Putumayo was a disputed territory between Colombia, Brazil and Peru, situated in the Amazon region.
}

Irish nationalism, he ended up, for the first time in his life, signing the petition on behalf of Roger Casement because, after all, he believed the Casement affair was an Irish affair, "His interest was in Ireland and Ireland had nothing to do with Europe politically: it was outside apart" (FOSTER, 2003, p. 519). According to Séamas O' Síocháin (2008), Yeats even went as far as to address the Home Secretary directly, "I have never before written to an English minister on an Irish question, but I am convinced that the execution of Sir Roger Casement will have so evil effect that I break this habit of years" (p. 464, WB Yeats to Home Secretary, 14/07/1916, PRO HO 144/1936/...45).

Foster asserts that the tension after the rebellion was translated into creative energy and that Dora Sigerson, prolific writer from Dublin and W. B. Yeats's acquaintance, was working on the verses which would be printed as Poems of the Irish Rebellion, 1916 and sent to W. B. Yeats that year. According to Maureen Murphy (2010), there is no mention whatsoever of Roger Casement's name in "Easter 1916" (1916), and his next poem, "Sixteen dead men", which although does not mention his name either, it becomes implicit that he is one of the sixteen dead men. It was written between 1916 and 1917, but it was only published in 1920, and it shows how Yeats begins to get actively involved in the conflict that Ireland was facing, as his poetry would gradually become a symbol of his political standing.

Following Casement's death and the negative outcome of the circulation of the so-called sodomite Black Diaries, supposedly written in the Amazon together with an official report on the atrocities against the Indians, the issue was silenced for many years, but never forgotten by his true supporters. Therefore, it was only in the 1930's, after William. P. Maloney published The Forged Casement Diaries, that the debate was once again raised concerning the way in which Roger Casement's alleged homosexuality had been used first to influence the opinions of his friends and supporters like Arthur Conan Doyle, George Bernard Shaw, Alice Stopford Green, his cousin Gertrude Banister, among others - against clemency for his trial for treason twenty years before (FOSTER, 2003). This was the opportunity Yeats needed to consummate his old wish to write openly about him as he "was shocked by the use of his diaries, not the imputation of homosexuality which - given his fin-de-siècle tolerance and current interest in the vagaries of sexual behaviour - was hardly likely to bother him" (FOSTER, p. 569).

In 1936, he told the writer and friend Ethel Mannin, of his wish to write something about Casement because, to his mind, he felt Casement did not deserve his fate due to his benevolent character: 
Casement was not a very able man, but he was gallant $\&$ unselfish, \& had surely his right to leave what he would have called an unsullied name. I long to break my rule against politics \& call these men criminals but I must not. Perhaps a verse may come to me, soon or a year hence (YEATS, 1936, apud FOSTER, 2003, p. 569)

Yeats soon broke his rule and composed two ballads on Casement being the first called "Roger Casement" (October-November 1936), which he decided to get printed and sung in public as a political gesture. According to Foster, the ballad, which was to be sung at the Abbey and broadcast on the national network by Radio Eirann, denounces those who had spread the charges on homosexuality after the Black Diaries became a public affair, preventing in the first instance his reprieve, in the second, his becoming an Irish martyr like the other fifteen rebels executed by the British for taking part in the 1916 Rebellion. Although the poem was highly acclaimed by some, Eamon de Valera having praised it for its scorning of the forgers, it was criticized by others for its bad rhymes: "The only English comment is in the Evening Standard, which points out my bad rhymes \& says that after so many years it is impossible to discuss the authenticity of the diaries. (The British government has hidden them for years)" (DLW, p. 126 apud, JEFFARES, 1968, p. 468).

Yeats's criticism was ultimately aimed at Sir Alfred Noyes, "Come Alfred Noyes and all the troupe/ That cried it far and wide" (YEATS, October-November, 1936), who claimed to have read excerpts of the Black Diaries when working at the British Foreign Office and had spoken against Casement at the time of his trial but then repented. The poem also criticised Oxford Professor Gilbert Murray who had "said that Roger Casement deserved death if ever treason merited such punishment" (NY Times, 1916).

Yeats thought it absurd that, be them genuine or not, this set of intimate homosexual diaries would be used if not as further evidence to kill Casement, to keep people from being sensitive towards his hanging and preventing him from becoming a martyr. He shared this feeling with his close friend Dorothy Wellesly revealing a quite forward way of conceiving sexuality that would deviate from the standard Victorian family pattern. According to Lucy McDiarmid Yeats's letter discloses a wish that Casement be a homosexual and the diaries genuine: "it would be a great relief to me if they were so submitted to me and proved genuine. If Casement were a homosexual what matter! But if the British government can with impunity forge evidence to prove him so no unpopular man with a cause will ever be safe" (YEATS, apud MCDIARMID, 2005, p. 190).
Therefore, the reader is left with several ways to approach both his Casement poems considering that they tackle aspects as relevant and diverse as biography, homosexuality, forgery, martyrdom etc. What follows is a reading of Yeats's second Casement poem, "The Ghost of Roger Casement" (December, 1936), bearing in mind how the representation of Roger Casement as a ghost brings to the fore uncanny elements of Celtic legends and folklore; as a result, Yeats's political views in relation to British Imperialism and Irish nationalism are disclosed.

\section{A reading of "The ghost of Roger Casement"}

According to Connor Cruise O'Brien, the only work that can be compared to Cathleen ni Houlihan, one of the most celebrated plays in Irish theatre in terms of Yeats's political views is "The Ghost of Roger Casement", first drafted in 1936, almost twenty years after his death. In this poem, the harshness of his politics is intermingled with nationalistic propaganda, while it becomes tinged by the uncanny presence figure of the ghost, frequent in Irish folklore.

It was not casual that Yeats decided to portray Roger Casement as a ghost seeking vengeance against the injustice that was done to him. In Fairy and folk tales of the Irish peasantry (1888) Yeats defines ghosts, Thevshi or Tash in Irish, as beings that "live in a state intermediary between this life and the next. They are held there by some earthly longing, or duty unfulfilled, or anger against the living" (p. 84). According to The encyclopaedia of Celtic mythology and folklore (2004), the ghost is considered a folkloric figure because the otherworld and the land of the dead blend together in the Celtic mind in such a way that it becomes difficult to distinguish between the ghosts of dead humans from those diminished divinities called fairies.

Patricia Monaghan (2004) affirms that not all people became ghosts; only those who suffered an interruption of the normal course of life, such as a young mother who died in childbirth and was concerned for the safety of her child; such an upset soul could return to haunt house and family. There are also more ordinary occasions on which elders who die after a full life sometimes returned trying to maintain the regular activities they undertook in the world of the living "taking a pipe by the fireside" (MONAGHAN, 2004, p. 211), more as a matter of habit than as a way to affect those who have not yet died. Other kinds of ghosts would be those who died violent deaths, who could sometimes be seen haunting the location where they parted.

It is this image of the wandering ghost that can be associated with Roger Casement for, in the first place, 
he died without accomplishing his goals when he went back to Ireland from Germany in 1916 - either to stop the Rising or to die in it - in the second, his dying wish was not attended to because since he was convicted for treachery he was not buried in Murlough Bay, in northern Ireland, but in Glasnevin cemetery, in Dublin. This image of Casement as a ghost inhabiting some kind of limbo or purgatory, in Yeatsian terms, has, nevertheless, become quite a commonplace after "The Ghost of Roger Casement". Casement's representation as a ghost has, since, been appropriated in several works of fiction and drama written up to this date. Among the most well known is David Rudkin's Cries from Casement as his bones are brought to Dublin (1974), about the exhumation of Casement's body from Pentonville prison in England, in 1965 and his reburial in Glasnevin, in Dublin and Michael Carson's The knight of the flaming heart (1995), a novel about the return of Casement's ghost to fulfil some of the issues that were left unresolved after his death, among others.

Another significant aspect to be considered is that both Casement poems were composed as ballads, for to Yeats's mind "the folk song is still a living thing in Ireland. Much of the national feeling in Ireland has been sustained by ballads" (FOSTER, p. 571). It can be said that form and content become one, as the ballad is the typical Irish folk song which, in this case, makes use of the mythological figure of the ghost to convey a nationalist message: the ghost of Roger Casement has returned to haunt John Bull, the personification of Britain. "The Ghost of Roger Casement" is composed of four stanzas, interspersed by the haunting refrain "The ghost of Roger Casement is beating at the door". In the first couple of verses in the first stanza a question is posed as an unrecognizable noise comes from the threshold, which symbolizes a place or state of transition, like a purgatory, neither the world of the living, nor dead, but a limbo where phantasmagoric beings inhabit:

$\mathrm{O}$ what has made that sudden noise?

What on the threshold stands?

It never crossed the sea because

John Bull and the sea are friends;

But this is not the old sea

Nor this the old seashore.

A decisive historical fact about Casement's life is implicit in the second verse: "It never crossed the sea because/ John Bull and the sea are friend;", for this "It" that the speaker refers to was at the time confined in England and had "never crossed the sea" back to where it belonged, for domineering John Bull was by then friends with the sea, and would not permit "it" to cross the waters to reach its homeland. One infers that this "it" that is held in England is the body, and consequently the ghost of Roger Casement, that has been impeded to rest in Ireland, has come back to claim revenge for he has suffered much injustice inflicted by John Bull, who, at the time of Casement's death in 1916, still held maritime hegemony and Ireland was part of the United Kingdom. What is more, as the poem was published in 1936 it refers to the time when the body of Roger Casement was still forbidden to be taken to rest in Ireland, according to his last wish that was uttered to his cousin Gertrude while waiting for the result of the appeal in Pentonville Prison: "Go back to Ireland, and don't let me lie in this dreadful place - take my body with you and let it lie in the old churchyard in Murlough Bay" (GERTRUDE apud MCDIARMID, 2005, p. 186).

Different from 1916, in the 1930's, when the poem was written and published, Ireland was already a Republic independent from Britain, thus the sea is no longer "the old sea", as Britain no longer controlled the seashore. In Casement's time, however, this menace against the English maritime supremacy could also have come from Germany, for it was the country that was England's enemy and that could have turned out victorious from the First World War; and this fear that Germany could eventually supersede Britain is clearly expressed in his diaries: "The English have become afraid of the Germans, afraid of German expansion, of German commercial training, of the German fleet even - and so the entente with France has become more and more a necessity to her statesmanship" (EDM, Rio de Janeiro, 15 September 1909, apud MITCHELL, 2010).

In the second stanza, the speaker of the poem utters that in the old days John Bull had had his days of glory:
John Bull has stood for Parliament, A dog must have his day, The country thinks no end of him, For he knows how to say, At a beanfeast or a banquet, That all must hang their trust Upon the British Empire, Upon the Church of Christ.

The reference to John Bull's eloquence at beanfeasts and banquets show that he, the personification of Britain, was once powerful, as a dog that may starve until it is lucky, or clever enough, to find what to eat. This metaphor of the dog that Yeats applies in the poem means that the golden age of the British Empire had occurred by chance, for it could have happened to any other country that had made the most of its fortune, which of course introduces the matter dealt with in the third stanza: 
John Bull has gone to India

And all must pay him heed,

For histories are there to prove

That none of another breed

Has had a like inheritance,

Or sucked such milk as he,

And there's no luck about a house

If it lack honesty.

The reader may note that one of John Bull's strategies to keep the empire together was its powerful discourse, which Casement much criticized after his time in the Congo, of bringing light into the so-called dark continents of Africa, India and later, indirectly, into the Americas in exchange for its invaluable human and natural resources. In this sense, it was, according to the poem, through his verbal persuasiveness that John Bull held the trust of his followers in countries like Ireland, who were taught from the earliest of ages to trust the United Kingdom and the Church, as it is stated in the previous stanza.

Furthermore, in these last two verses Yeats makes a clear statement of his nationalist ideals and political positioning in favour of Ireland and against Britain while comparing the United Kingdom to a house which lacks honesty, and thus lacks luck. It is this absence of luck that would make it susceptible to be haunted by ghosts who have suffered some kind of injustice within its realm, as is the case of the ghost of Roger Casement haunting John Bull. Yeats makes use of the image of the ghost, which also conveys the idea of a being that survives the passage of time, one that will last until eternity and become a timeless token of the evil consequences of British imperialism. Furthermore, the implications of using a phantasmagorical being to express his views becomes a tool that aids touching on taboo subjects to a certain society.

This idea can be supported by Freud's conception of the uncanny as a way of dealing with subjects that have once been familiar, but have become unfamiliar, that is, unheimlich (uncanny or unhomely), or frightening, such as a situation of domination or revolution. One of these taboo subjects is the predicament faced by an Ireland that did have no choice left but to allow the British justice to execute and hang sixteen men whose crime had been to fight for the freedom of their country and countrymen in 1916.

Another taboo subject approached indirectly in "The Ghost of Roger Casement" is the Black Diaries controversy, elaborated in Yeats's aforementioned poem "Roger Casement". This controversy is implicit here, for it is along with his alleged treasonous act of seeking German support to form the Irish Brigade to fight in the 1916 Irish Rebellion, the main reason why Casement's body, and consequently his ghost, is held in
John Bull's island. The Diaries reveal another aspect of Freud's concept of the uncanny that can be applied to Casement, which is Schelling's idea of the unheimlich as something that "ought to have remained... secret and hidden but has come to light" (FREUD, 1919), for it was the discovery of his alleged homosexual diaries that determined his fate, for they ruined any chances of an appeal being held by his supporters, who were given copies of it.

The final stanza shows that different from Casement, John Bull, after his death, has managed to be buried where he wished, in his family tomb:

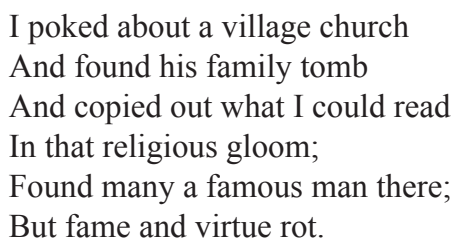

The site has been visited by the speaker of the poem, under a gloomy and, again, uncanny, religious atmosphere. He concludes, after seeing many other famous men buried six feet under, that no matter what their deeds had been, not only does the physical body rot, but also "fame and virtue", meaning that one day, as history has already proven, the great empires, such as the Roman, the Ottoman, Mongol, the Byzantine and the British itself, shall all come to their end.

\section{Draw round, beloved and bitter men, Draw round and raise a shout; The ghost of Roger Casement Is beating on the door.}

Therefore, the final verses of "The Ghost of Roger Casement" urge not just Yeats's countrymen, but also other peoples who have become embittered due to the aftermath of imperialism, to unite and shout the name of the ghost of Roger Casement, who was killed prematurely and has, since, become the epitome of the ills of imperialism, to continue to haunt John Bull's island while beating at his door.

\section{Conclusion}

In a nutshell, this paper has aimed to establish links that have connected two honourable men: the Irish revolutionary Roger Casement and the writer William Butler Yeats, who had in common not just the fact of being nationalist Anglo-Irish Protestants, but also of having expressed admiration for one another. As it has been shown, Casement had read and commented on Yeats's poems and plays; Yeats, on the other hand, admired Casement for his benevolent character as well as 
his humanitarian deeds and, above all, he found his cause an Irish cause and, therefore worth fighting, thus, going against his vows of not meddling with politics. Although this work has focused on his second poem, "The Ghost of Roger Casement", both his Casement poems written in the 1930's reveal profound sympathy for the "incorrigible Irishman" after his death.

To conclude, Casement's ghost would be the epitome of the uncanny, for his home country, Ireland, has become unheimlich (uncanny, umhomely), or unfamiliar to him since his imprisonment, and it will only become heimlich (homely), or familiar enough for him to be able to rest once two matters are settled: first, the controversy surrounding the Black Diaries, which were brought to light to end the reprieve that could have saved his life and were, especially in Yeats's time, used to blacken his name. And, finally, once he is unburied yet again and taken to his resting place in Murlough Bay, which would put a full stop to the conflict between Ireland and Britain.

\section{The ghost of Roger Casement WB Yeats, 1936}

O what has made that sudden noise?

What on the threshold stands? It never crossed the sea because John Bull and the sea are friends; But this is not the old sea Nor this the old seashore. What gave that roar of mockery, That roar in the sea's roar?

\section{The ghost of Roger Casement} Is beating on the door.

John Bull has stood for Parliament, A dog must have his day, The country thinks no end of him, For he knows how to say, At a beanfeast or a banquet, That all must hang their trust Upon the British Empire, Upon the Church of Christ.

The ghost of Roger Casement Is beating on the door.

John Bull has gone to India And all must pay him heed, For histories are there to prove That none of another breed Has had a like inheritance, Or sucked such milk as he, And there's no luck about a house If it lack honesty.

\author{
The ghost of Roger Casement \\ Is beating on the door. \\ I poked about a village church \\ And found his family tomb \\ And copied out what I could read \\ In that religious gloom; \\ Found many a famous man there; \\ But fame and virtue rot. \\ Draw round, beloved and bitter men, \\ Draw round and raise a shout;
}

The ghost of Roger Casement

Is beating on the door.

\section{References}

FOSTER, Roy. W. B. Yeats: a life - the arch-poet 1915-1939 (v. II). Oxford: Oxford University Press, 2003.

FREUD, Sigmund. The uncanny. Available at: $<$ http://web.mit. edu/allanmc/www/freud1.pdf $>$. Last consulted on: 25 April, 2013.

INGLIS, Brian. Roger Casement: the biography of a patriot who lived for England, died Ireland. New York: Hardcourt, Brace, Jovanovich, 1973.

JEFFARES, Alexander N. A commentary on the "Collected poems of W.B. Yeats”. Stanford: Stanford UP, 1968.

MCDIARMID, Lucy. The afterlife of Roger Casement. The Irish art of controversy. London: Cornell University Press, 2005.

MITCHELL, Angus. Roger Casement in Brazil: rubber, the Amazon and the atlantic world 1884-1916. São Paulo: Humanitas, 2010.

MONAGHAN, Patricia. The encyclopaedia of Celtic mythology and folklore. New York: V. B. Hermitage, 2004.

MURPHY, Maureen. Ghosts and Roger Casement in the works of W. B. Yeats. ABEI Journal, São Paulo, v. 12, p. 73-90, 2010.

O'BRIEN, Conor Cruise. Ancestral voices: religion and nationalism in Ireland. Chicago: The University of Chicago Press, 1995.

O’SÍOCHÁIN, Séamas. Roger Casement: imperialist, rebel, revolutionary. Dublin: Lilliput Press, 2008.

YEATS, William Butler. Roger Casement. The collected poems of William Butler Yeats. Hertfordshire: Wordsworth Editions, 2000. p. 261.

YEATS, William Butler. The ghost of Roger Casement. The collected poems of William Butler Yeats. Hertfordshire: Wordsworth Editions, 2000, p. 262.

MURRAY defends hanging. The New York Times, New York, August 4, 1916. Available at: <http:/query.nytimes.com $/ \mathrm{mem} /$ archive-free/pdf?res=FA0D17FA355B17738DDDAD0894D04 05B868DF1D3>. Last consulted on: 25 April, 2013

Recebido: 30 de janeiro de 2015

Aprovado: 29 de maio de 2015

Contato: mariana.bolfarine@usp.br 